\title{
Equilibrative Nucleoside Transporter 2
}

National Cancer Institute

\section{Source}

National Cancer Institute. Equilibrative Nucleoside Transporter 2. NCI Thesaurus. Code C104547.

Equilibrative nucleoside transporter $2(456 \mathrm{aa}, \sim 50 \mathrm{kDa})$ is encoded by the human

SLC29A2 gene. This protein plays a role in nucleoside transport for nucleotide salvage. 